\title{
A review: influence of refractories on steel quality
}

\section{Jacques Poirier}

CEMHTI, CNRS UPR3079/Université d'Orléans, 1D avenue de la Recherche Scientifique, 45071 Orléans

Cedex 2, France

e-mail: jacques.poirier@univ-orleans.fr

\section{Key words:}

Refractories; steel quality; oxide cleanliness; desulphurisation; Ca treatments; clogging of submerged nozzles; oxygen pick up

\section{Received 8 July 2015}

Accepted 4 August 2015

\begin{abstract}
Chemistry and inclusion control are two of the main keys to the production of quality steel products. The refractory materials have a direct influence on the quality of elaborate grades at different levels: (i) The control of solute elements such as carbon, sulphur, nitrogen, hydrogen, oxygen. (ii) The prevention of non-metallic inclusions. A good knowledge of the metal-slag-refractory products interactions is consequently necessary in order to have a better control of elaboration procedures. Among all the points brought up, we could mention all the developments that will limit the contribution of refractory products in clogging phenomena, carbon pick up and atmospheric re-oxidation, in conjunction with efforts of the metallurgists to produce clean steels.
\end{abstract}

U nder the pressure from users and faced with competition from other materials, steel makers have to propose steel grades with narrower composition ranges, lower guaranteed contents of certain residuals and controlled inclusion size distributions to obtain reproducible service properties. These results can only be reached by a strict control of processes and also of products used during steel making [1]. In particular, steel cleanliness and purity requirements make the selection of refractory products more and more important.

Certain metallic residuals or non metallic impurities have a marked influence on the physical and mechanical properties of steels. Figure 1 summarizes the role that non metallic elements could have on various properties of the metal.

Consequently, the steel maker must conceive more and more complex elaboration modes to eliminate these elements and limit pollution risks.

Significant progress has been made lately on the control of elements $\mathrm{C}, \mathrm{H}, \mathrm{N}, \mathrm{O}, \mathrm{P}, \mathrm{S}$ for which contents from a few ppm to several tens of ppm are currently obtained on the most sensitive grades, whenever necessary. For example, after vacuum treatment
Table 1. Lower limits of residual elements in steel making elaboration.

\begin{tabular}{ccccccc}
\hline Elements & $\mathrm{P}$ & $\mathrm{C}$ & $\mathrm{S}$ & $\mathrm{N}$ & $\mathrm{H}$ & $\mathrm{O}$ \\
\hline $\mathrm{ppm}$ & 10 & 5 & 5 & 10 & $<1$ & 5 \\
\hline
\end{tabular}

in industrial conditions, a liquid steel with $C$ content $<20 \mathrm{ppm}$ is presently possible. In the same way, the sulphur levels for HIC steels or oxygen levels for bearing grades can be lowered to values of a few ppm, which, in this case, makes it possible to increase dramatically the operating life of bearings. Table 1 shows typical limits of these elements for current steel making technologies.

In this context, the impact of refractory products on the metal may be assessed at three levels:

- the possibility to keep the chemical composition of the liquid steel within the specified range for a given process;

- the achievement of the required metal cleanliness, i.e. the amount and nature of non-metallic inclusions;

- the prevention of defects concerning the steel surface. 


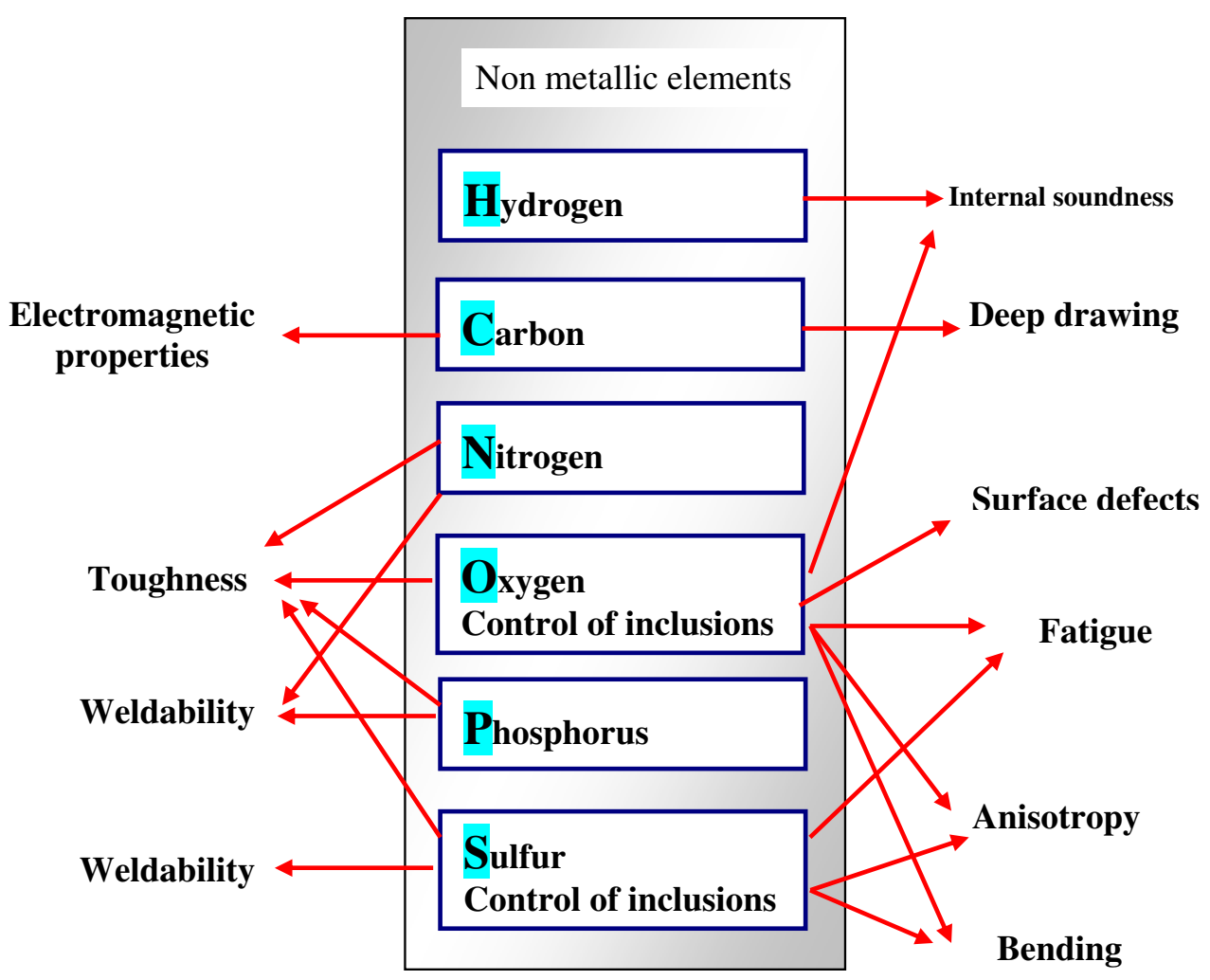

Fig. 1. Influence of non metallic elements on steel properties.

\section{Influence of refractories on steel quality and inclusionary cleanliness}

Adjustment of this high level of quality and of steel cleanliness within the steel plant production cycle is accomplished during secondary metallurgy and is maintained during continuous casting.

Taking metallurgical aspects more and more into account imposes a new approach of interactions between metal, slag, atmosphere and refractory products [2]. These interactions are generally controlled by the microstructures, the phases distribution, the chemical and mineral composition of the refractory products.

Figure 2 summarises the main classes of refractory in relation with the quality and metal cleanliness.

The refractory parts and products most involved in the problems of metal quality are:

- The steel ladle and the degassing devices which may be a source of pollution even if subsequent floatation is still possible. For example:

- corrosion of the magnesia refractory lining by the slag and cracking of the alumina refractory wall have an impact on the composition of the desulphurisation slag;

- carbon pick up of 5 to 10 ppm by the steel may result from magnesiacarbon refractories pollution.

- The tundish lining, which can have a polluting action (exchange of oxygen, hydrogen, silicon and magnesium between the magnesia refractory and the steel).

- The stopper which may be a source of reoxidation.

- The submerged nozzle materials with their direct and indirect role on clogging and unclogging, leading to metal contamination by alumina particles or clusters. 


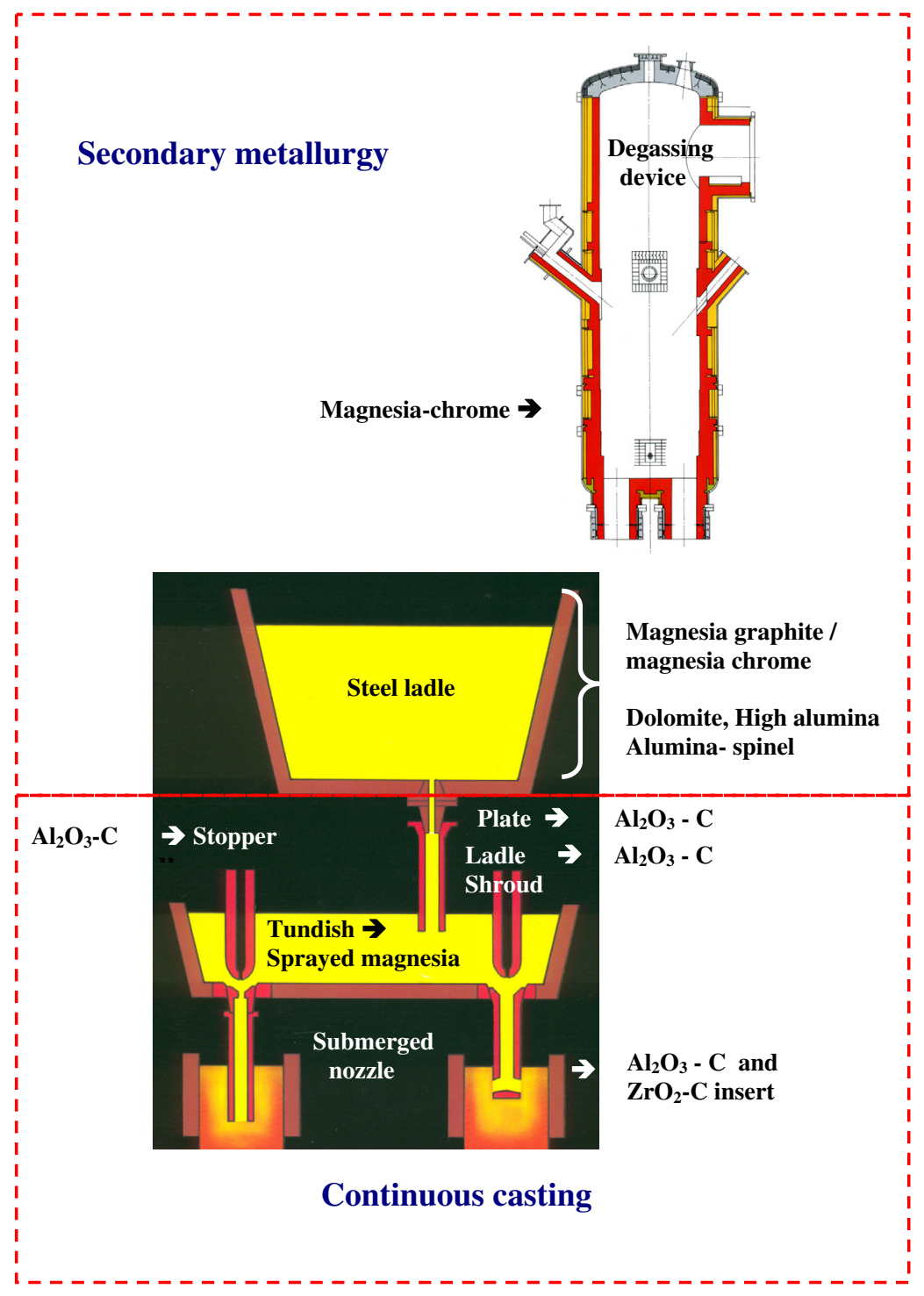

Fig. 2. Main classes of refractories in relation with the steel quality and inclusionary cleanliness.

\section{Interactions of refractories and steel during the processes of secondary metallurgy}

With the development of secondary metallurgy, the role of the steel ladle has changed. It has become a metallurgical reactor in the steel making process.

In a steel ladle or in a degassing device, many reactions between refractories, steel and slag can contribute to degrading the steel quality:

- direct dissolution of the refractory with or without precipitation;

- dissociation, volatilisation;
- oxido-reduction reactions, between an oxide and a metallic element;

- combination of the refractory and a nondissolved element present in the steel (inclusion).

\subsection{Reactions between refractories, steel and slag [3,4]}

\subsubsection{Dissolution}

Among the refractory compounds used in steel ladles, only carbon can be affected by a dissolution in steel. For example carbon 


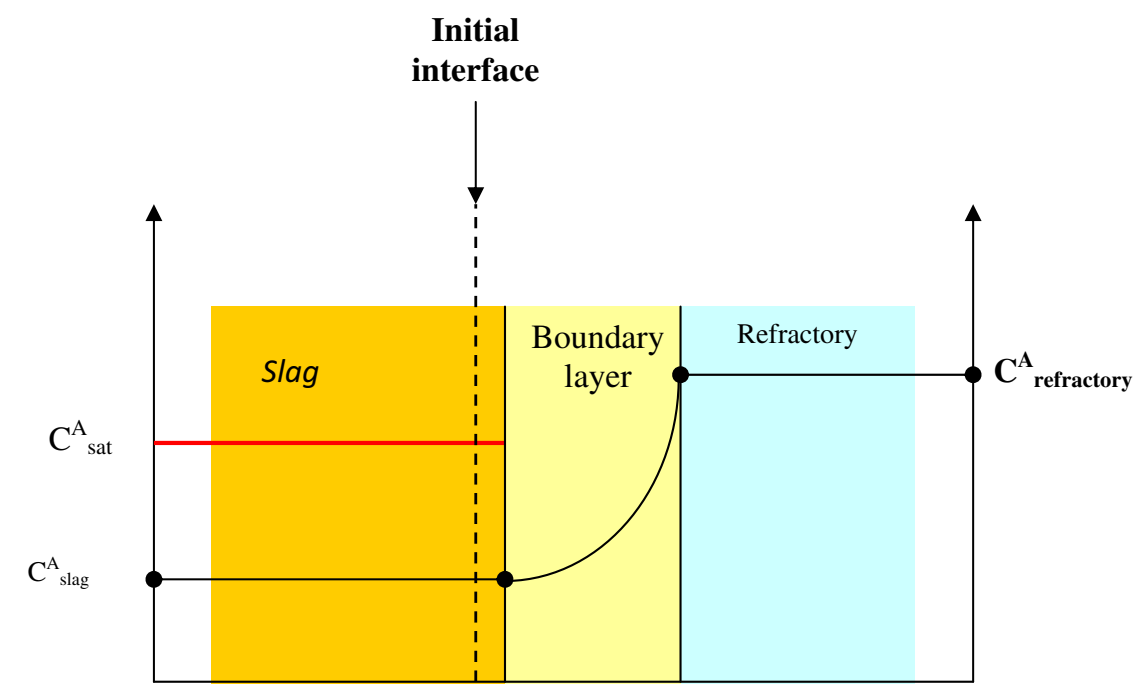

Fig. 3. Dissolution of the refractory by slag: gradient composition at the interface slag/refractory.

(residual carbon from the binders or additional carbon in $\mathrm{MgO}-\mathrm{C}$ bricks) can be dissolved directly into the liquid steel.

The corrosion between refractory lining and slag is often controlled by a direct dissolution, chemical exchanges are controlled by a boundary layer at the liquid/refractory interface [5]. The gradient of chemical potential, which is usually assimilated to a composition gradient, is the driving force of the corrosion process (Fig. 3). Two elementary steps govern the dissolution mechanism:

- a thermo chemical reaction at the solid/liquid interface;

- a diffusion of species.

The dissolution wear rate is expressed by Nersnt's equation:

$$
\mathrm{d}\left[C^{\mathrm{A}}\right] / \mathrm{d} t=h\left(C_{\mathrm{s}}^{\mathrm{A}}-C^{\mathrm{A}}\right) \text { with } h=D / e
$$

$-C_{\mathrm{s}}^{\mathrm{A}}$ : saturation solubility of $\mathrm{A}$ in the liquid phase

- $C^{\mathrm{A}}$ : concentration of $\mathrm{A}$ in the liquid phase outside the boundary layer

- $h$ : mass transport constant, $D$ : diffusion coefficient, $e$ : thickness of the boundary layer.

The dissolution rate decreases with decreasing $D$ or increasing $e$. To minimise the corrosion rate, it is recommended to minimise $\left(C_{\mathrm{s}}^{\mathrm{A}}-C^{\mathrm{A}}\right)$.
The saturation solubility of the refractory oxides can be determined using thermodynamic calculations or phase diagrams.

Consider the dissolution of a $\mathrm{MgO}-\mathrm{C}$ refractory by a $\mathrm{CaO}-\mathrm{SiO}_{2}$ slag $\left(\mathrm{CaO} / \mathrm{SiO}_{2}\right.$ weight ratio of 0.9 and $T=1630{ }^{\circ} \mathrm{C}$ ) [6]: if the liquid slag is saturated with magnesia $\left(\approx 19 \%\right.$ wt of $\mathrm{MgO}$ ) then $\mathrm{d}\left[\mathrm{C}^{\mathrm{MgO}}\right] / \mathrm{d} t=0$ and it cannot dissolve $\mathrm{MgO}$ (Fig. 4).

The dissolution mechanism can be heterogeneous with the precipitation of new phases in the interface layer [7]. In this case, the wear rate will decrease.

The examination of the microstructures of refractories after laboratory corrosion tests is extremely useful to determine the mechanisms of chemical attack.

Laboratory corrosion tests, based on the static crucible method, were performed with a bauxite brick and an $\mathrm{Al}_{2} \mathrm{O}_{3}-\mathrm{CaO}$ slag (weight ratio of $\mathrm{Al}_{2} \mathrm{O}_{3} / \mathrm{CaO}=1$ ). Typical characteristics of the bauxite refractory are listed in Table 2.

For corrosion testing, the crucible was filled with $40 \mathrm{~g}$ of slag and heat treated in air at $1600{ }^{\circ} \mathrm{C}$ using electric furnace. Heating rate was $15^{\circ} \mathrm{C} / \mathrm{min}$ up to $900^{\circ} \mathrm{C}$ and $9^{\circ} \mathrm{C} / \mathrm{min}$ up to $1600^{\circ} \mathrm{C}$. After $6 \mathrm{~h}$ firing, the crucible was quenched in cold water $\left(T \approx 8^{\circ} \mathrm{C}\right)$ in order to avoid partial crystallisation of the liquid phase during cooling.

Figure 5 shows a microstructure of the precipitation zones of the bauxite refractory after corrosion. 


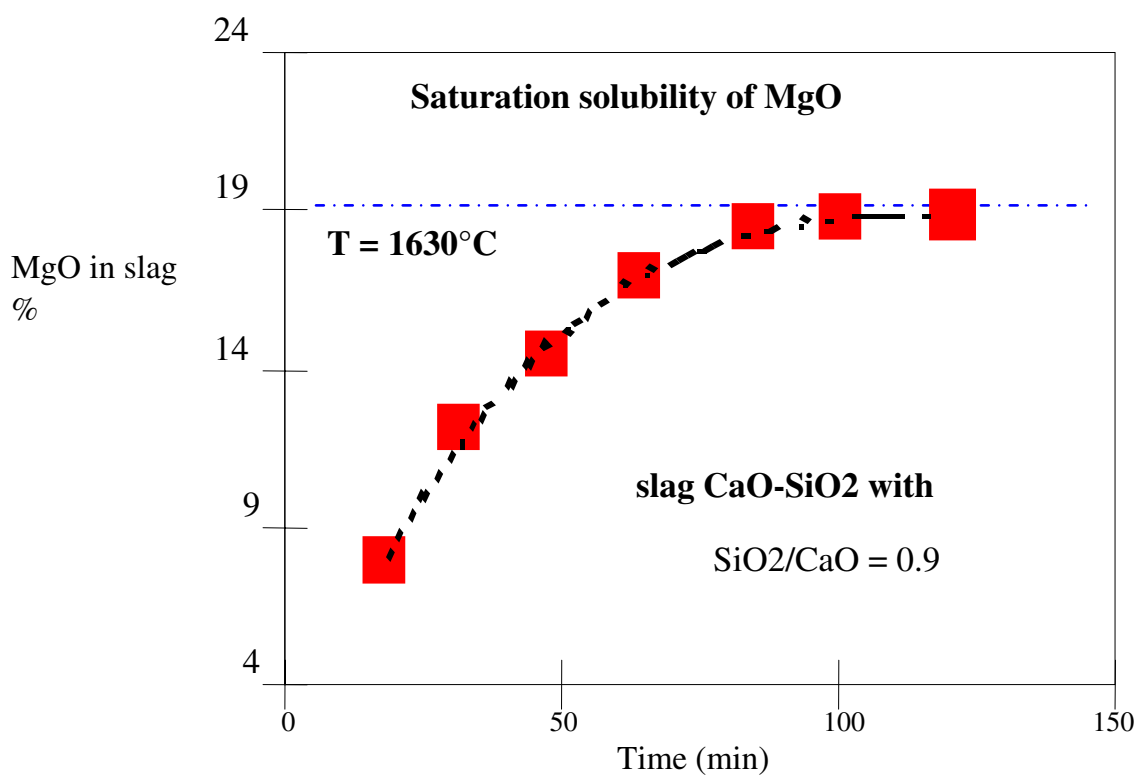

Fig. 4. Dissolution of magnesia in $\mathrm{MgO}-\mathrm{C}$ refractory by $\mathrm{CaO}-\mathrm{SiO}_{2}$ slag for different times, at $1630{ }^{\circ} \mathrm{C}$.

Table 2. Typical chemical composition, bulk density and apparent porosity of bauxite bricks.

\begin{tabular}{cccccccc}
\hline \multicolumn{4}{c}{ Composition $(\mathrm{wt} \%)$} & & Mineral phases & Bulk density $\left(\mathrm{g} / \mathrm{cm}^{3}\right)$ & $\begin{array}{c}\text { Apparent } \\
\text { porosity }(\%)\end{array}$ \\
\cline { 1 - 4 } $\mathrm{Al}_{2} \mathrm{O}_{3}$ & $\mathrm{SiO}_{2}$ & $\mathrm{Fe}_{2} \mathrm{O}_{3}$ & $\mathrm{TiO}_{2}$ & other & & 16.17 \\
\cline { 1 - 5 } 79.5 & 14 & 1.6 & 2.9 & 2 & $\begin{array}{c}\mathrm{A}^{* * *}, \mathrm{M}^{* *}, \mathrm{TiO}_{2}{ }^{*},(\mathrm{Al}, \mathrm{Fe})_{2} \\
\mathrm{TiO}_{5}^{*} \text { vitreous phase }\end{array}$ & 3.24 & 16 \\
\hline
\end{tabular}

A: corundum, M: mullite. (***: major; ${ }^{* *}$ : mean; *: minor).

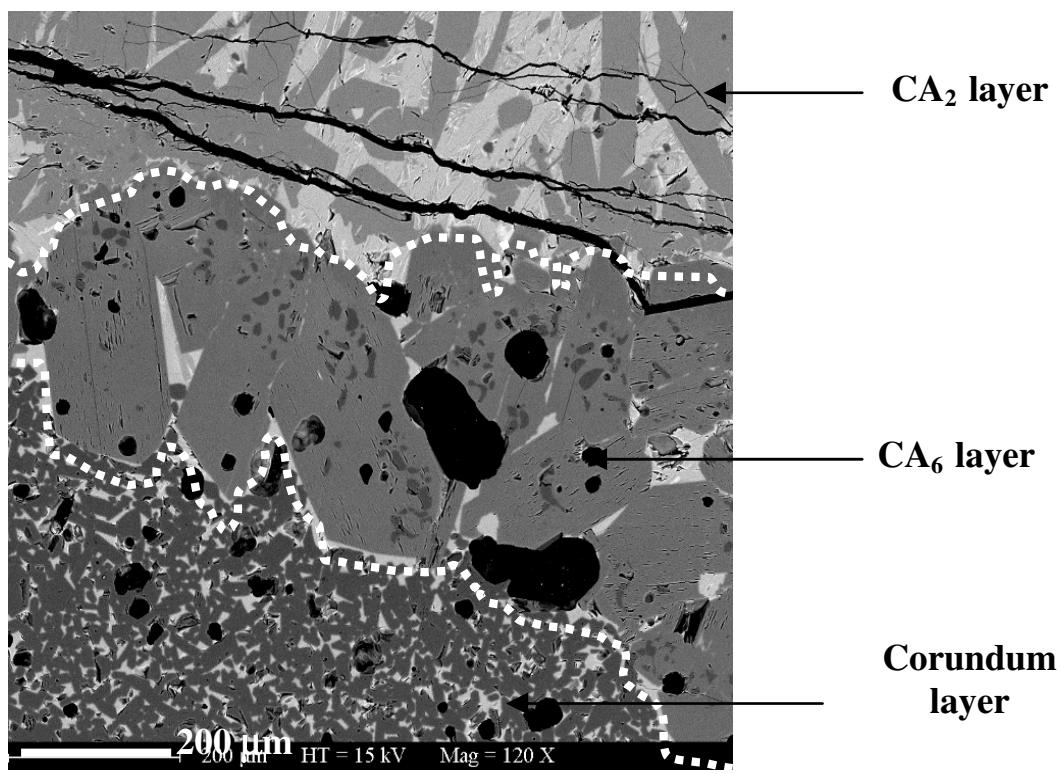

Fig. 5. Microstructure of bauxite bricks corroded by $\mathrm{Al}_{2} \mathrm{O}_{3}-\mathrm{CaO}$ slag (weight ratio of $\mathrm{Al}_{2} \mathrm{O}_{3} / \mathrm{CaO}$ $=1$, lab crucible test); Backscattered electrons S.E.M micrographs on polished sections (Transition between the three mono-mineral layers of the precipitation zone). 
Table 3. Mechanism of submerged nozzles clogging by alumina build-up.

\begin{tabular}{|c|c|c|c|}
\hline & Outside & Refractory sidewall of the nozzle & Hot face \\
\hline $\begin{array}{l}\text { Starting } \\
\text { conditions }\end{array}$ & Air & $\begin{array}{l}\text { Permeable refractory made of } \\
\text { oxides }+ \text { carbon }+ \text { porosity }\end{array}$ & Molten steel containing $\underline{\mathrm{Al}}, \underline{\mathrm{O}}, \underline{\mathrm{C}}$ \\
\hline \multirow{2}{*}{$\begin{array}{c}\text { General } \\
\text { mechanisms }\end{array}$} & \multirow[t]{2}{*}{$\mathrm{O}_{2}$ leakage } & $\begin{array}{l}\text { Temperature generates direct } \\
\text { reduction of some oxides by the } \\
\text { carbon and direct oxidation of carbon }\end{array}$ & \multirow[t]{2}{*}{$\begin{array}{l}\text { - } \begin{array}{l}\text { Reoxydation of some sub- } \\
\text { oxides }\end{array} \\
-\quad \text { Oxidation of aluminium }\end{array}$} \\
\hline & & $\begin{array}{l}\text { - Negative presure generates gas } \\
\text { transfer }\end{array}$ & \\
\hline \multirow{8}{*}{\multicolumn{2}{|c|}{$\begin{array}{l}\text { Various } \\
\text { mechanisms }\end{array}$}} & Dissolution of the refractory carbon & \\
\hline & & \multirow{7}{*}{$\begin{array}{l}-\mathrm{Na}_{2} \mathrm{O}+\mathrm{C} \rightarrow 2 \mathrm{Na}(\mathrm{g})+\mathrm{CO}(\mathrm{g}) \\
-\mathrm{K}_{2} \mathrm{O}+\mathrm{C} \rightarrow 2 \mathrm{~K}(\mathrm{~g})+\mathrm{CO}(\mathrm{g}) \\
-\mathrm{SiO}_{2}+\mathrm{C} \rightarrow \mathrm{SiO}(\mathrm{g})+\mathrm{CO}(\mathrm{g}) \\
-\mathrm{SiO}_{2}+2 \mathrm{C} \rightarrow \mathrm{Si}(\mathrm{g})+2 \mathrm{CO}(\mathrm{g})\end{array}$} & At the interface \\
\hline & & & \multirow[t]{2}{*}{$-\mathrm{CO} \rightarrow \underline{\mathrm{C}}+\underline{\mathrm{O}}$} \\
\hline & & & \\
\hline & & & \multirow{3}{*}{$\begin{array}{c}\text { - Reoxidation oxidation } \underline{\mathrm{Al}} \\
\mathrm{Na}, \mathrm{K}, \mathrm{SiO}, \mathrm{Si}\end{array}$} \\
\hline & & & \\
\hline & & & \\
\hline & & & 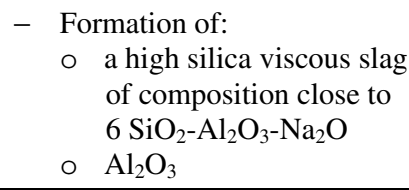 \\
\hline & \multirow[t]{3}{*}{$\mathrm{O}_{2}$ pick up } & Transfert of $\mathrm{O}_{2}$ and oxidation of carbon & At the interface \\
\hline & & $\mathrm{C}+1 / 2 \mathrm{O}_{2} \rightarrow \mathrm{CO}(\mathrm{g})$ & $\mathrm{CO}(\mathrm{g}) \rightarrow \underline{\mathrm{C}}+\underline{\mathrm{O}}$ \\
\hline & & & $3 / 2 \mathrm{O}_{2}+2 \mathrm{Al} \rightarrow \mathrm{Al}_{2} \mathrm{O}_{3}$ \\
\hline
\end{tabular}

The alteration of the refractory microstructure can be explained by dissolution-precipitation processes inside a liquid phase. Several mineral layers can be observed. The texture of the layers, as well as the shape and habit of the crystals, clearly indicates that they are precipitated slowly from a liquid phase and do not result from a fast crystallisation during cooling. Corundum from the first layer shows well-formed crystals that differ clearly from those of the transformed bauxite. The CA6 layer is still present, but in the case of an important corrosion of the refractory, when the remaining slag composition shows a significant change: the CA2 layer is absent.

\subsubsection{Dissociation-volatilization}

Under normal pressure conditions and in the range of steel treatment temperatures, the oxides composing the refractories can not dissociate. This type of reaction can occur when vacuum degassing occurs $(\mathrm{RH}$, $\mathrm{RH} / \mathrm{OB}, \mathrm{DH}, \ldots$ ).
For example, let us consider the chromium volatilisation of the magnesitechrome lining in $\mathrm{RH} / \mathrm{OB}$ vacuum degassers [8].

While dissociation or volatilization of chromium oxides are of no consequence when used at atmospheric pressure, it does become a problem under even a vacuum of $10^{-3}$ atmosphere.

The observations (see Fig. 6) have clearly shown different factors of corrosion, namely:

- the presence of iron oxides and attack by slag;

- the influence of vacuum and atmosphere;

- the impregnation-spalling process.

The microstructure of a used brick (Fig. 7) illustrates the process of destruction. The micrograph shows a shiny corroded area with a thickness of 1-2 mm. The periclase grains are saturated with iron oxide, associated with a swelling effect with dislocations and the formation of compounds with a melting point lower than the treatment temperature. The refractory, being infiltrated, is worn out by a densification-spalling mechanism. 


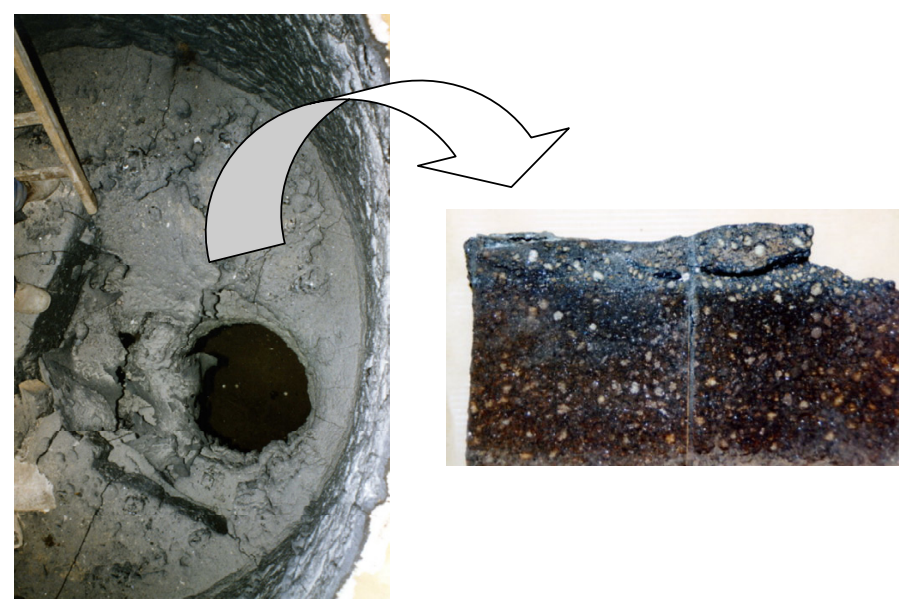

Fig. 6. Corrosion by iron oxides of a bottom in a vacuum degasser (RH/OB) and structural spalling of a brick after use.

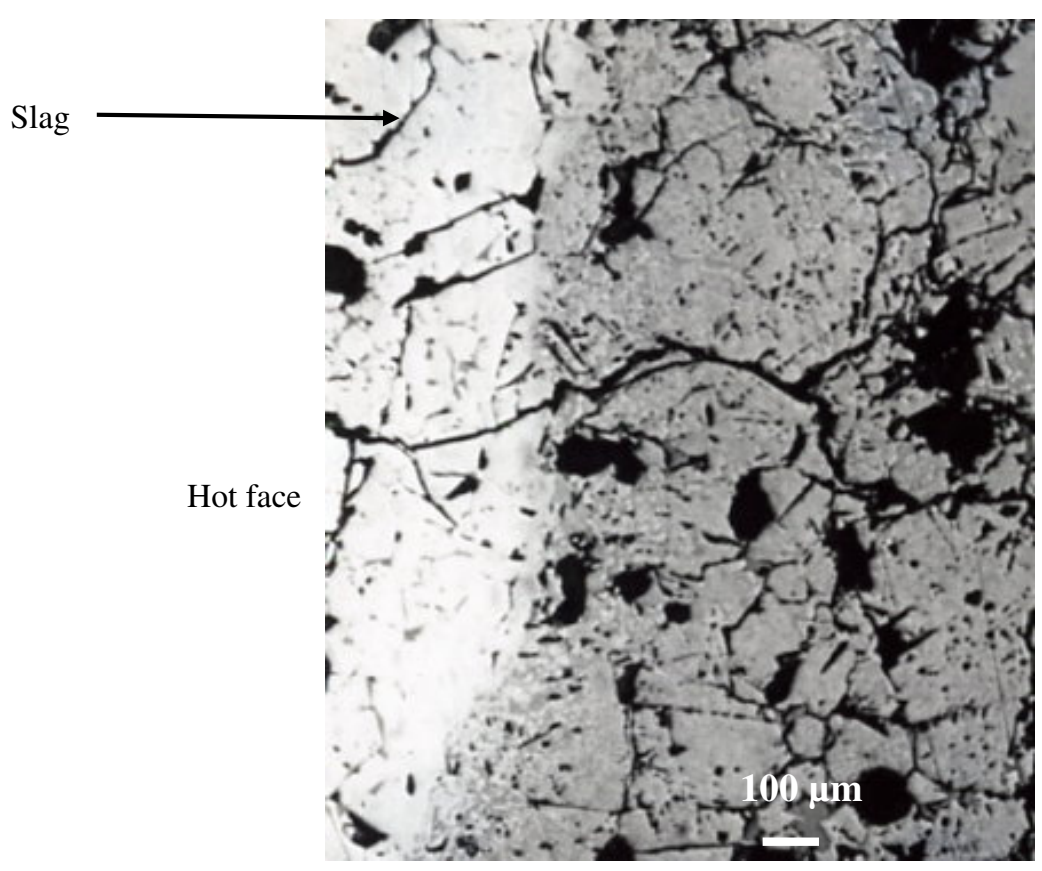

Fig. 7. Microstructure of the hot face of a magnesia-chrome refractory after use in a RH/OB vacuum degasser.

By comparing X-ray diffraction patterns obtained on samples taken respectively from near the hot face, behind the used bricks, and from new bricks, the following evolution is also shown:

- An evolution of the spinel composition between a solid solution of the ( $\mathrm{Mg} \mathrm{Fe})$ $(\mathrm{Cr} \mathrm{Al})_{2} \mathrm{O}_{4}$ type for the new brick and a solution of the type $\mathrm{Mg}(\mathrm{Al} \mathrm{Fe})_{2} \mathrm{O}_{4}$ for an area located near the corrosion front (see Fig. 8).
- This evolution results in a net disappearance of the chromium.

The chromium oxide volatilisation is a complex phenomenon:

- the $\mathrm{Cr}_{2} \mathrm{O}_{3}$ oxide dissociates with formation of several possible oxide species;

- it depends upon the nature of the gaseous atmosphere;

- the partial pressure of oxygen plays an important role; volatility increases with an increase in $\mathrm{P}\left(\mathrm{O}_{2}\right)$; this is due to the fact 

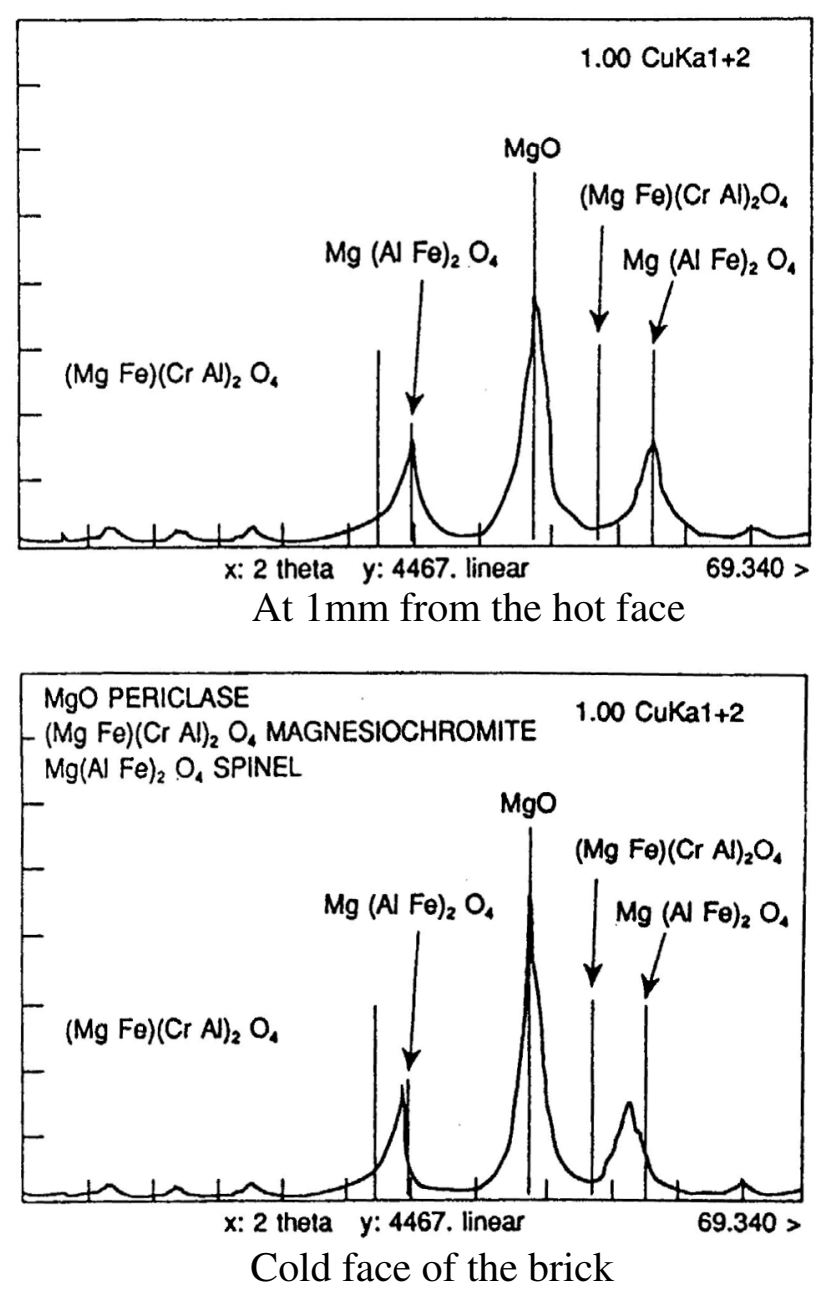

Fig. 8. Evolution of the X-ray diffraction patterns of magnesite chrome refractories after use in a $\mathrm{RH} / \mathrm{OB}$ vacuum degasser. The spinels of general formulation $\mathrm{A}^{2+} \mathrm{B}_{2}^{3+} \mathrm{O}_{4}^{2-}$ crystallise in the cubic crystal system, with the oxide anions arranged in a cubic close-packed lattice and the cations A and B occupying some or all of the octahedral and tetrahedral sites in the lattice. At $1 \mathrm{~mm}$ from the hot face of the refractory, the XRD powder pattern can be indexed with $\mathrm{Mg}(\mathrm{AlFe})_{2} \mathrm{O}_{4}$ spinel. At the cold face of the brick, the XRD pattern is clearly different. While a good match is obtained with the $\mathrm{Mg}(\mathrm{AlFe})_{2} \mathrm{O}_{4}$ spinel at $1 \mathrm{~mm}$ from the hot face, a better indexation of the pattern can be achieved by adjusting the cubic lattice parameters of the spinel phase.

that $\mathrm{CrO}_{3}$ and $\mathrm{CrO}_{2}$, as gaseous species, are richer in oxygen than $\mathrm{Cr}_{2} \mathrm{O}_{3}$.

Under such conditions, the chromium oxide can decompose and release pure chromium.

\subsubsection{Oxido-reduction reactions (between an oxide and a metallic element)}

These metal-refractory reactions promote the reduction and the progressive disappear- ance of the refractory oxides. A re-oxidation of the liquid steel occurs which gives rise to the formation of solid inclusions.

- $\mathrm{Al}_{2} \mathrm{O}_{3}, \mathrm{MgO}$ and $\mathrm{CaO}$ are stable when faced with $\mathrm{Mn}, \mathrm{Al}$, Si and $\mathrm{C}$, while this is not true for $\mathrm{Al}_{2} \mathrm{O}_{3}$ and $\mathrm{MgO}$ with regard to $\mathrm{Ca}$. A calcium treated steel can, therefore, attack an aluminous lining, or react partially with a magnesia or dolomitic refractory;

- $\mathrm{SiO}_{2}$ and $\mathrm{Cr}_{2} \mathrm{O}_{3}$ turn out to be especially reactive with all the elements found in steel. In particular, an aluminium deoxidized steel can react with a refractory containing silica or chromium oxide.

For example, consider the reduction of the silica by the dissolved manganese:

$$
2 \underline{\mathrm{Mn}}+\mathrm{SiO}_{2} \rightarrow 2 \mathrm{MnO}+\underline{\mathrm{Si}}
$$

This reaction develops rapidly and is not curbed by the growth of a protective layer because the $\mathrm{MnO}$ formed combines with the silica of the lining to form low fusion point phases $\left(1250{ }^{\circ} \mathrm{C}\right)$ which are quickly eliminated from the refractory. Corrosion reactions can develop easily, and except for high silicon steels, the inclusions formed are always liquid. In fact, their composition obtained by microanalysis is generally very near that of the rhodonite $\mathrm{MnSiO}_{3}$ (see Fig. 9).

\subsubsection{Carbo-reduction}

At high temperature, a great number of redox or carbo-reduction reactions may occur simultaneously, resulting from the reduction as:

- secondary phases present in the refractories;

- carbonaceous raw materials (graphite, amorphous carbon);

- metallic elements.

As an example, consider the possible carboreduction reactions in the case of magnesia carbon refractories in contact with slag in steel ladles.

Magnesia can be reduced to form magnesium as a gas and $\mathrm{CO}$. At equilibrium and at $1600{ }^{\circ} \mathrm{C}$, the partial pressure of magnesium is as high as $1 \times 10^{-2}$ at. But several 


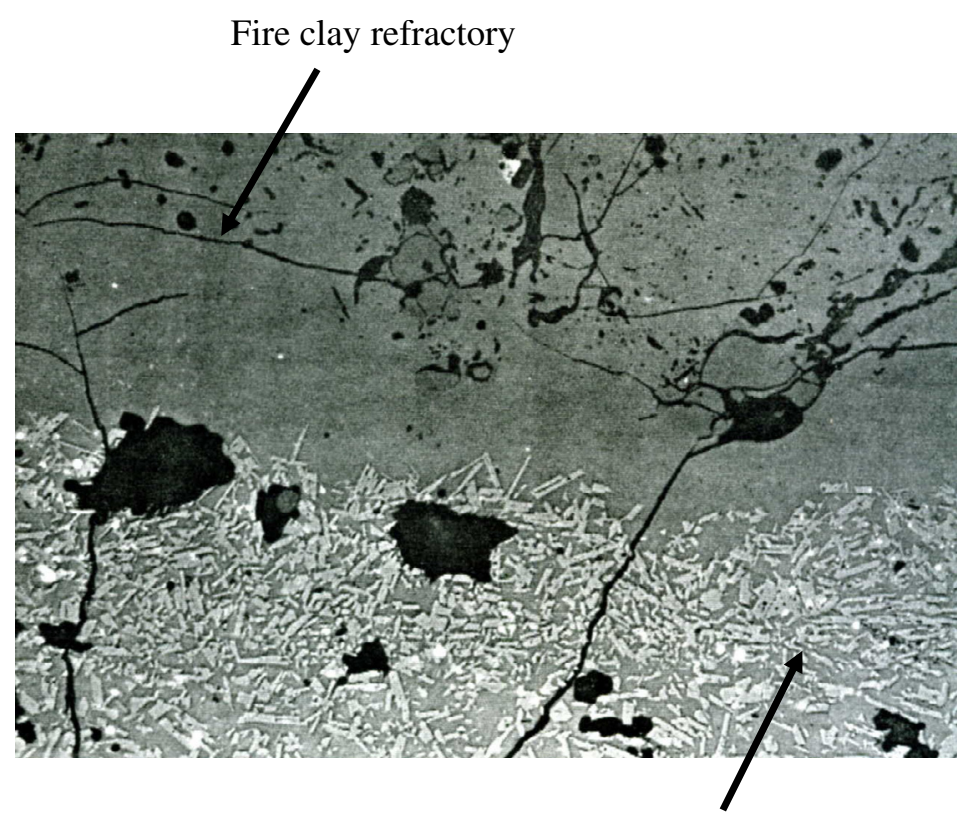

Silicate of manganese crystals

Fig. 9. Reduction of silica from clay refractory by manganese dissolved in steel; formation of silicate-manganese crystals (whose composition is close to $\mathrm{MnSiO}_{3}$ ) at the interface clay refractory/steel.

other reduction reactions can occur simultaneously, resulting from the reduction of other oxides to be found in the brick, or from the reduction of the periclase grains by the metallic additions or the carbides which may form, when antioxidants are used. All these reactions lead to the formation of gaseous species, either $\mathrm{Mg}(\mathrm{g}), \mathrm{SiO}(\mathrm{g})$ or $\mathrm{Si}(\mathrm{g})$, which may diffuse to the exterior of the brick.

Near the hot face, where more oxidising conditions prevail $\left(\mathrm{PO}_{2}=10^{-8}\right.$ at), the previous gaseous species $\mathrm{Mg}$, $\mathrm{SiO}$ and/or Si react with either $\mathrm{CO}_{2}$ or $\mathrm{O}_{2}$ to revert back to an oxide form. This leads to the well-known phenomenon of magnesia transport to compensate for carbon oxidation on the hot face.

$\mathrm{MgO}$ is reduced within the brick. Both $\mathrm{Mg}(\mathrm{g})$ and $\mathrm{CO}$ diffuse away towards the hot face; in the decarburised zone resulting from the oxidation of carbon at $1600{ }^{\circ} \mathrm{C}$ when $\mathrm{PO}_{2}$ is $>10^{-16}$ at, the $\mathrm{Mg}$ gas can recombine to form condensed $\mathrm{MgO}$ (Fig. 10). Such net transfer of $\mathrm{MgO}$ has seldom been observed under practical steel making conditions

\subsection{Metallurgical consequences}

Potential consequences of steel ladles refractory behaviour with respect to liquid metal and/or slags are examined using a few metallurgical examples concerning:

- control of oxide cleanliness;

- steel desulphurisation;

- Ca treatments of alumina de-oxidation inclusions;

- elaboration of ultra low carbon steels.

\subsubsection{Control of oxide cleanliness}

Oxide cleanliness is measured by the total mass of oxide inclusions that can be formed in the liquid steel. It is determined by thermodynamics, the treatment temperature and time.

Clean steel elaboration is dependent upon the four fundamental steps necessary to remove oxide inclusions from steel:

- generation of the inclusion;

- transport of the inclusion to the slag/steel interface;

- separation of the inclusion to the interface;

- removal of the inclusion from the interface.

Aluminium (or silicon) additions to steel have been used to transform soluble oxygen 


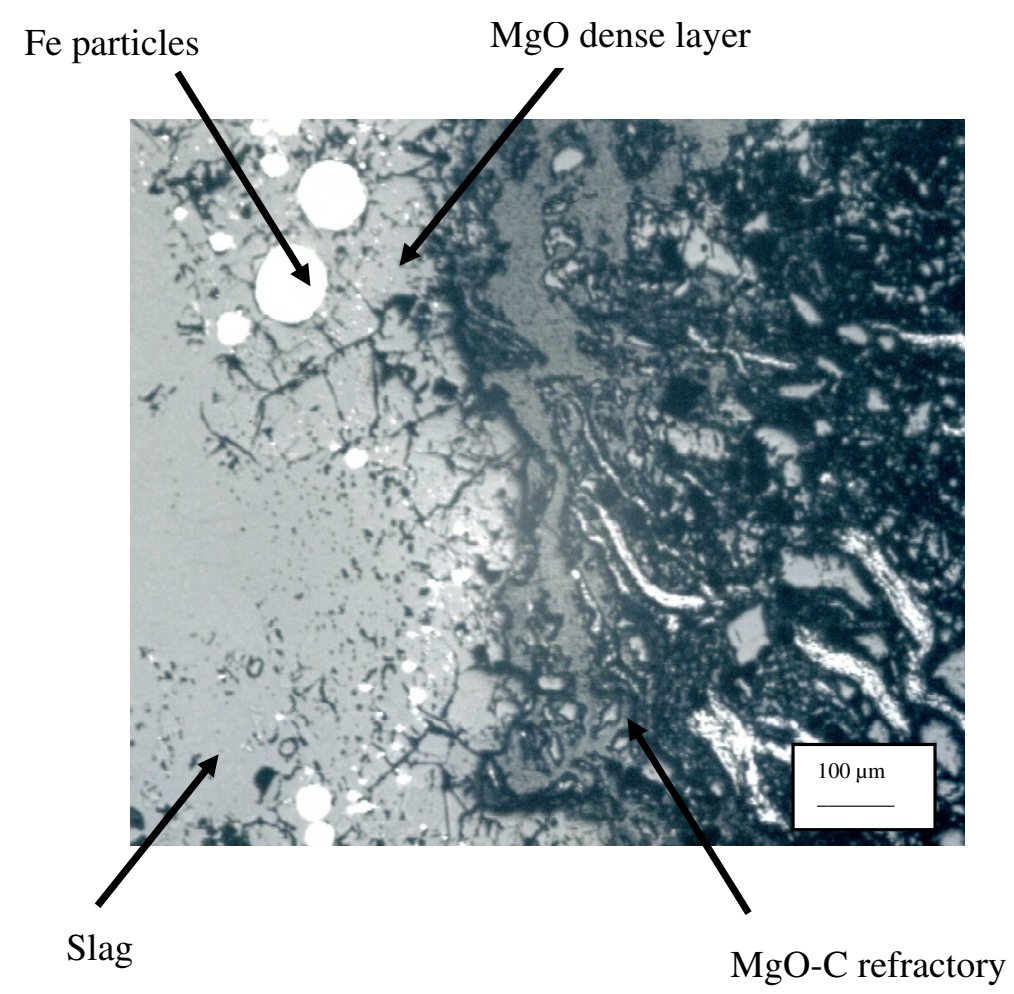

Fig. 10. Carbo-reduction of magnesia in a $\mathrm{MgO}-\mathrm{C}$ refractory at high temperature; microstructure of a $\mathrm{MgO}$ dense layer at the hot face of a magnesia-carbon (steel ladle slag line).

into alumina (or silica). Thus after aluminium addition at a ladle metallurgy facility, total oxygen minus soluble oxygen is a measure of the mass of alumina in the steel and total oxygen levels are used as a measure of steel cleanliness.

Today, total oxygen contents less than $20 \mathrm{ppm}$ are currently obtained for aluminium killed steels and even in the case of specialty steels with medium or high carbon contents (bearing steels, for example), for which utmost precautions are taken to reach levels lower than $5 \mathrm{ppm}$ in the product [9].

However, various mechanical properties can be affected by the presence, even in very small numbers, of exogenous, generally large inclusions resulting, in particular, from the mechanical or chemical deterioration of refractory products (erosion of particles after dissolution by the steel of phases serving as a binder). As corrosion and erosion problems are time and temperature dependent, these degradations often occur during extended ladle treatment times and long sequence casting. They also tends to increase with certain steel grades (such as high manganese or Ca treated steels).
The choice of refractory products for metal cleanness must also take into account the metal-slag-refractory reactions which may occur during elaboration. It is indeed not rare to find often undesirable elements in the liquid steel or in the inclusions coming from impurities or even made of refractory products: Ti from bauxite, $\mathrm{Cr}$ from magnesia-chrome, $\mathrm{C}$ from aluminagraphite. The calculation models make it possible to determine potential transfer of elements between refractories, slag and metal [10]. They can be used as a guide to select refractory product qualities best adapted to the elaboration of a given grade. It should be recalled that the mineralogical composition of the products used has an influence on the kinetics of these reactions. Solutions should be based upon developing highly stable refractories for given steel grades.

\subsubsection{Steel desulphurisation}

Desulphurisation of liquid steel is obtained by metal-slag stirring in secondary metallurgy. The lime in the ladle slag reacts 


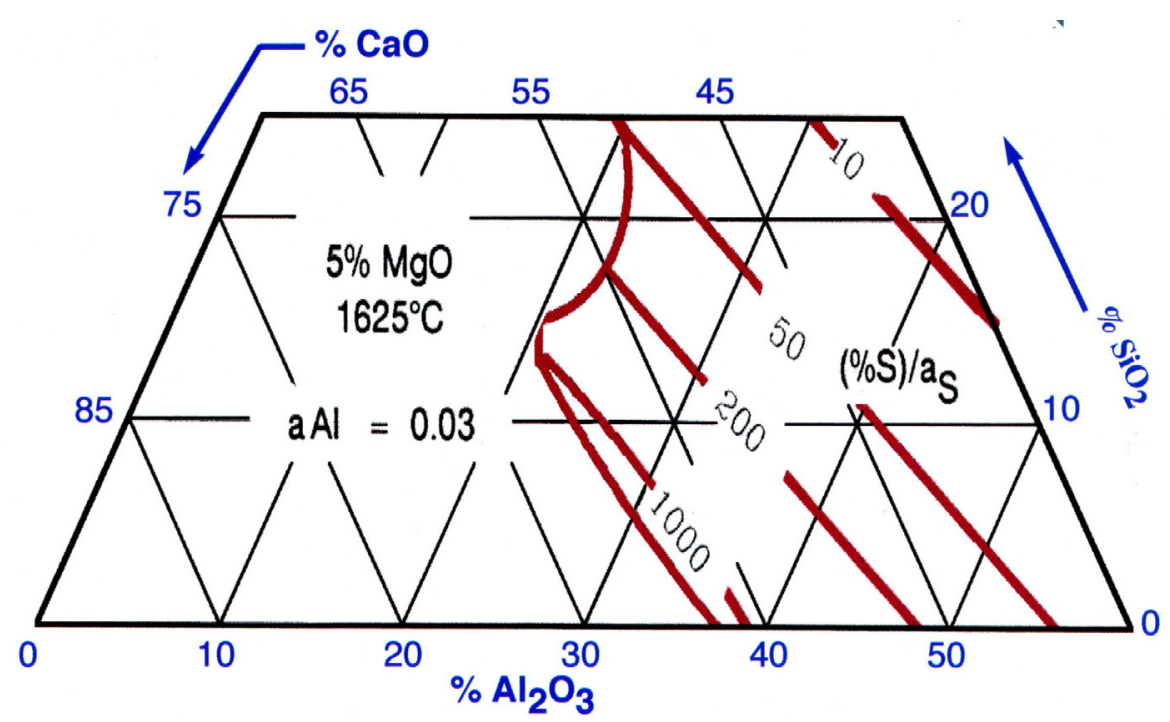

Fig. 11. Sulfur partition coefficient at equilibrium between liquid slags of the $\mathrm{CaO}-\mathrm{Al}_{2} \mathrm{O}_{3}-\mathrm{SiO}_{2}-$ MgO system and steel with $a_{(\mathrm{Al})}=0.03$, at $1625^{\circ} \mathrm{C}$.

with the sulphur dissolved in the steel and with a deoxidation element, forming calcium sulphide and the oxide of the reduction compound.

$$
\begin{aligned}
\mathrm{CaO}+\underline{\mathrm{S}}=\mathrm{CaS} & +\mathrm{O} \text { and } \underline{\mathrm{O}}+\underline{\mathrm{X} i}=\mathrm{XiO} \\
& \rightarrow \mathrm{CaO}+\underline{\mathrm{S}}+\underline{\mathrm{X}}=\mathrm{CaS}+\mathrm{XiO}
\end{aligned}
$$

For aluminium killed steels, rates of desulphurisation higher than $90 \%$ (with final sulphur contents less than $10 \mathrm{ppm}$ and even 5 ppm) can be obtained. Desulphurisation requires working with a liquid slag, close to lime saturation, and at low contents in oxides easily reducible by the aluminium from the metal. This is shown by the partition coefficient curves between slag and liquid metal in Figure 11 [11]. To obtain reproducible results in industrial conditions, it is, consequently, essential to control well the slag composition. Now, considering the narrowness of the composition domain of favourable slag, any refractory dissolution adding silica or alumina will cause the properties of desulphurisation of slag to deteriorate (Fig. 11). The behaviour of ladle refractories to slag corrosion was the object of extensive research [12]. The oxygen potential of the refractory products must be as low as possible. In laboratory tests, dolomite exhibits the best results, magnesite is somewhat poorer and magnesite/chromium are significantly worse. The results are degraded when bauxite refractories with a high oxygen potential are used. In industrial conditions, advanced desulphurisation can only be reached reliably and reproducibly in ladles with a basic lining. A deterioration of desulphurisation results may also be due to a bad control of the physical quality of slag (partially solid slag over-saturated in lime, for example). In a study on vacuum treatments in dolomite ladles, Bergmann et al. [13] have shown (Fig. 12) that the optimal slag compositions, concerning desulphurisation rates and the wear of the magnesia refractories, corresponded to a narrow domain of composition located around lime saturation.

\subsubsection{Ca treatments of alumina deoxidation inclusions}

One of the goals of these treatments, on aluminium killed steels, is to improve the castability of these grades by transforming the alumina deoxidation inclusions into liquid lime aluminate inclusions. These liquid inclusions, contrary to alumina, do not stick to the nozzle refractories, which they even tend to dissolve when they are too rich in lime.

During treatment, calcium, having a higher affinity for oxygen than most metallic elements used in iron and steel making, can reduce, at least partially, some constituents 


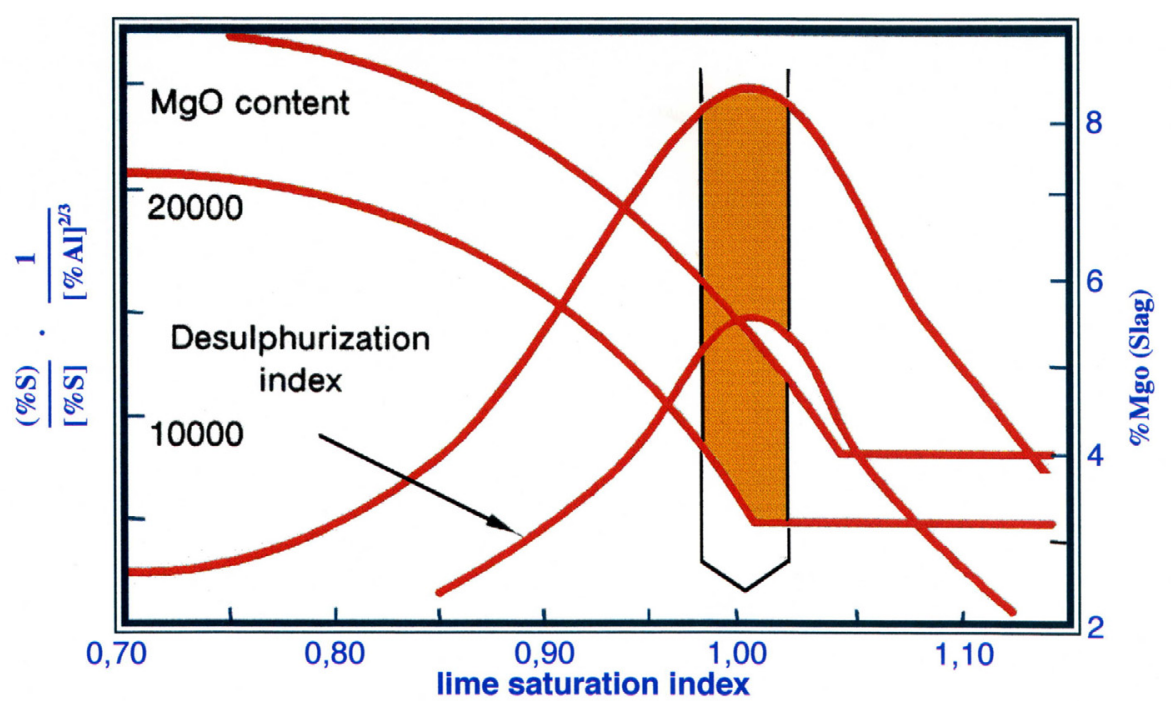

Fig. 12. Effect of degree of lime saturation of the slag on desulphurisation and refractory wear [13]. The two lines for each parameter (MgO content and desulphurization index) represent the dispersion zone of the measurements. The orange coloured region represent the theoretical target (optimal slag for desulphurisation and magnesia refractories). Lime saturation index lower 1 correspond to liquid slags. In practise, beyond lime saturation (index $>1$ ) solids are in suspension in the slag. Reproducible chemical and physical behaviour of slag cannot be expected.

of the refractories $\left(\mathrm{SiO}_{2}, \mathrm{Cr}_{2} \mathrm{O}_{3}, \mathrm{Al}_{2} \mathrm{O}_{3}, \ldots\right)$. A notable improvement in the efficiency of a calcium addition was, for example, noted when high alumina ladle refractories were replaced by dolomite or magnesia refractories, more stable with respect to alkalineearth elements. This transformation made it possible to increase drastically the percentage of ladles cast in billets without clogging of the calibrated nozzle [14].

However, even with the use of basic refractories, it must not be forgotten that an oxide such as magnesia is, from a thermodynamic point of view, less stable than lime and can be reduced by calcium, which leads to a transfer of magnesia towards the inclusions whose $\mathrm{MgO}$ content increases at the expense of $\mathrm{Al}_{2} \mathrm{O}_{3}$.

As an example, Figure 13 shows the average composition of inclusions obtained following too large an addition of SiCa to steel in a dolomite ladle. These inclusions, have a final composition of $55 \% \mathrm{MgO}-35 \% \mathrm{CaO}-$ $10 \% \mathrm{Al}_{2} \mathrm{O}_{3}$ after following the path shown on the figure during treatment. They are solid at casting temperature $\left(T_{\text {liq }}>2400{ }^{\circ} \mathrm{C}\right)$ and, like most solid inclusions, may stick to the refractory walls and especially participate in nozzle clogging.
The reliability of calcium treatment thus requires not only an optimisation of added quantities, but also an adequate selection of the refractory in contact with the metal.

\subsubsection{Elaboration of ultra-low carbon steels}

Ultra-low carbon steels, such as interstitial free steels (IFS), require a high oxygen content during decarburization (CO degassing) and the slag line of the steel ladle has long lasting contacts with iron oxide rich slag.

Carbon pick up strongly varies with the composition of ladle slag after deoxidation (Fig. 14).

The presence, in a limited amount, of these iron oxides in the slag can have a beneficial effect on the corrosion of magnesia carbon bricks used in the ladles. Indeed, in contact with $\mathrm{FeO}$, a protective $\mathrm{MgO}$ dense layer $[16,17]$ can be formed on the hot face of the $\mathrm{MgO}-\mathrm{C}$ refractories.

Inside the magnesia carbon brick, the following reaction occurs:

$$
\mathrm{MgO}(\mathrm{s})+\mathrm{C}(\mathrm{s}) \rightarrow \mathrm{Mg}(\mathrm{g})+\mathrm{CO}(\mathrm{g})
$$

At high temperature, magnesia is reduced by the carbon to form $\mathrm{Mg}$. $\mathrm{Mg}$ vapor is 


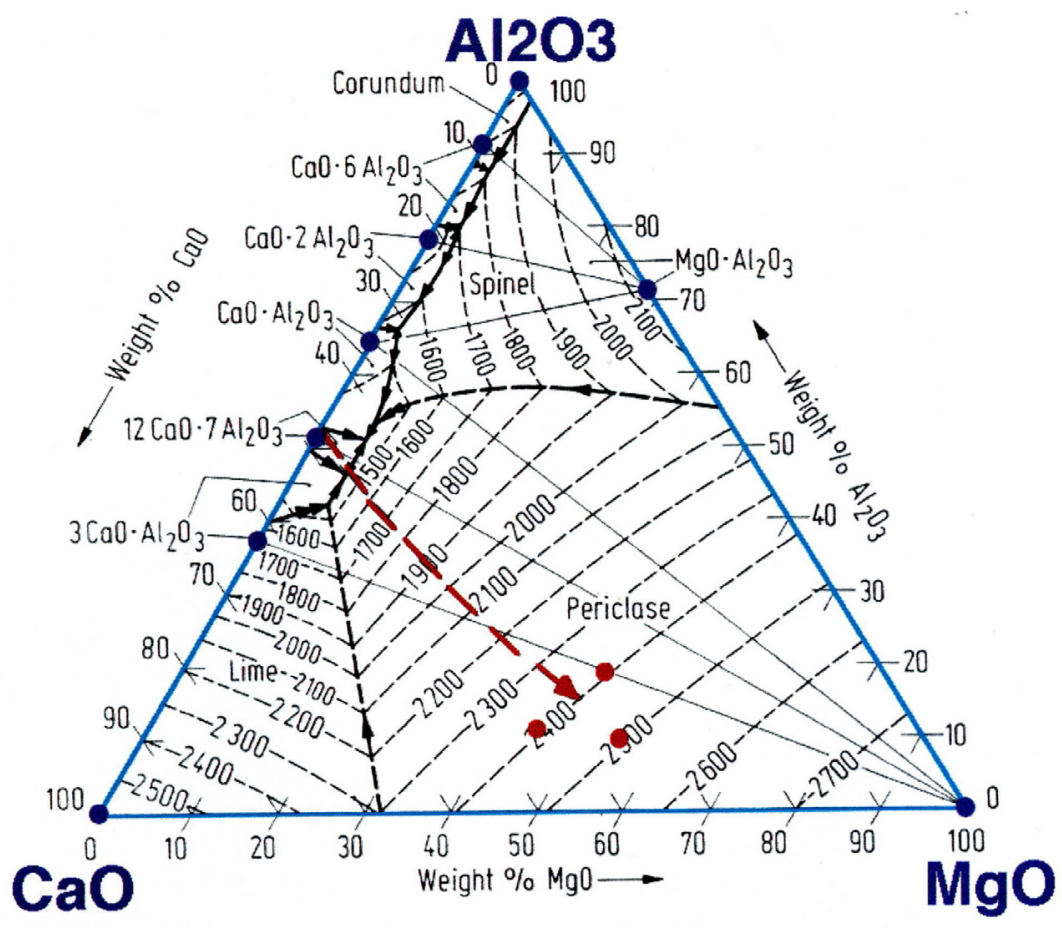

Fig. 13. Formation of inclusions in Al killed steels created by reaction of the dolomitic lining with calcium addition in excess [15]. The reduction by calcium lead to refractory inclusions. After complete solidification at equilibrium, compositions marked as red points, correspond to a mixture $\mathrm{CaO}, 3 \mathrm{CaO} . \mathrm{Al} 2 \mathrm{O} 3$, and $\mathrm{MgO}$.

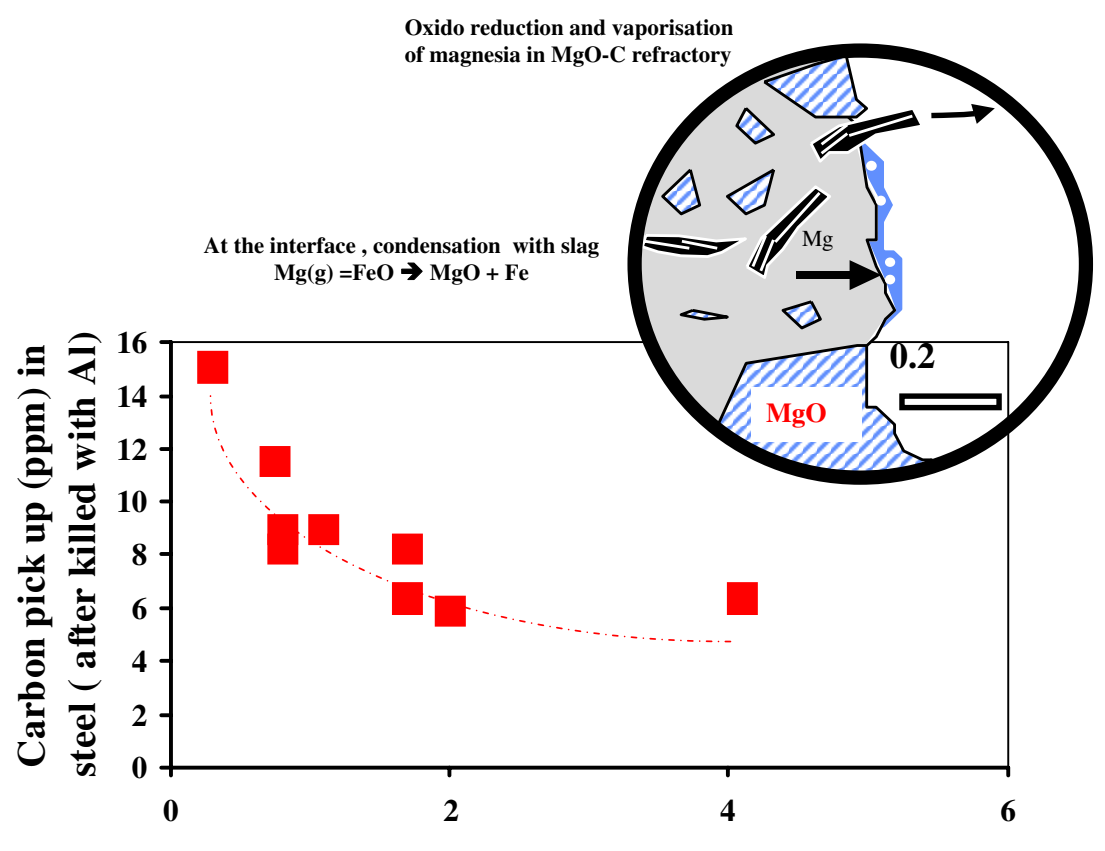

[Fe] $(\%)$ in slag

Fig. 14. Relationship between carbon pick up and iron content in slag for a ultra low carbon steel (killed aluminium) [6]. 
transported to the hot face where it is oxidized to a secondary $\mathrm{MgO}$ dense layer by reduction of iron oxides and precipitation of iron [6].

$$
\mathrm{Mg}(\mathrm{g})+\mathrm{FeO}(\mathrm{l}) \rightarrow \mathrm{MgO}(\mathrm{s})+\mathrm{Fe}(\mathrm{s})
$$

A careful control of service conditions such as the level of iron oxidation $\left(\mathrm{FeO}, \mathrm{Fe}_{2} \mathrm{O}_{3}\right)$ and the composition of the slag is required to trigger the formation of this secondary $\mathrm{MgO}$ dense layer $[2,17,18]$.

\section{Interactions of refractory materials and steel during continuous casting}

The role of shaped refractory parts used in continuous steel casting is to guide and protect liquid metal from the ladle to the mould where steel is solidified.

In continuous casting, it may be considered that the most relevant refractory parts and products in the problems of metal cleanliness are:

- First, the submerged nozzle materials with their direct and indirect role in clogging and unclogging, leading to metal contamination by alumina particles or clusters.

- Then, the tundish lining which can have a purifying or polluting action.

- Finally, the ladle shroud tube where reactions similar to the ones met in submerged nozzles can take place and the whole sliding gate system where the state of the plates after service indicates pollution risks.

\subsection{Submerged nozzles}

Submerged nozzles are, for the most part, alumina-graphite products. Clogging of submerged nozzles by alumina build-up (Fig. 15) constitutes one of the major sources of dysfunction of aluminum-killed steel continuous casting [19]. This detrimental buildup degrades the quality of the steel produced, reduces the casting sequences, and thus limits the productivity of the steel maker. Although this phenomenon has been studied for the last twenty years, it is not

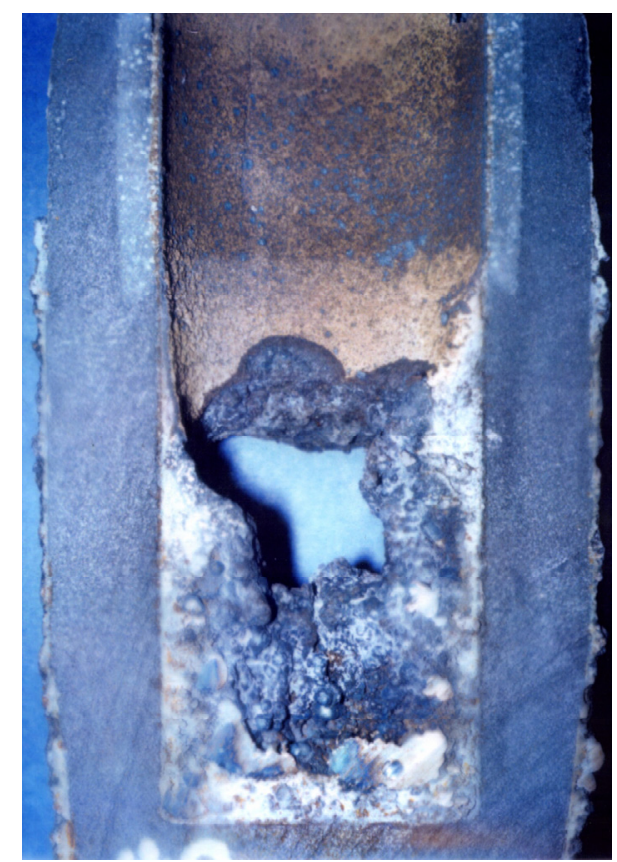

Fig. 15. Alumina build up clogging in a submerged nozzle.

very well understood yet. Build-up is known to be affected by parameters such as steel grade, steel cleanliness, flow conditions in the casting channel, beat flow control, refractory composition, and air leakage, but correlation to an exact cause is illusive. Several mechanisms of build-up are mentioned in the literature. They include: oxide precipitation and deposition on the nozzle bore due to a high thermal conductivity of the refractory, non uniform fluid flow within the nozzle resulting in dead spots of liquid steel, chemical wetting of the liner by the steel facilitating oxide deposition, air leakage through the refractory oxidizing aluminium-killed steel, refractory surface roughness enhancing oxide deposition, and the redox reactions supplying oxygen for dissolved aluminum oxidation and deposition. Although build-up may be affected by one or several of these mechanisms simultaneously, this paper focuses on the influence of the refractory composition on buildup.

\subsubsection{Clogging mechanism [20]}

The mechanism described herein focuses on the deposition of $\mathrm{Al}_{2} \mathrm{O}_{3}$ as a result of the 
thermo-chemical reduction of nozzle constituents coupled with the oxidation of the aluminium in the steel. In this scenario, the deposit builds up in the three following steps:

- dissolution of the carbon of the refractory into the steel;

- build-up of a first layer of deposit made up of $\mathrm{Al}_{2} \mathrm{O}_{3}$ and a vitreous phase by volatilization and oxidation reactions;

- oxidation of aluminum by carbon monoxide (CO).

\subsubsection{Carbon dissolution}

Superficial carbon dissolution from the refractory, occurring at the very beginning of the casting, results in a localized modification of the refractory/steel interface. Here, the activity of the aluminium in the steel increases as carbon activity increases. Overall, the steel chemistry is such that dissolved oxygen in the steel $\underline{O}$ is in equilibrium with the dissolved aluminium $\mathrm{Al}$. A localized increase in aluminium activity leads to the precipitation of alumina, forming a fledgling layer of alumina on the refractory surface via:

$$
2 \underline{\mathrm{Al}}+3 \underline{\mathrm{O}} \rightarrow \mathrm{Al}_{2} \mathrm{O}_{3}(\mathrm{~s})
$$

It is the decarburization of the refractory by the steel which triggers this reaction.

\subsubsection{Build- up of a first layer of deposit by volatilisation and oxidation reactions}

After the carbon dissolution, a layer composed predominantly of alumina particles and, to a lesser extent, a vitreous phase consisting of alumina, silica and alkalis is observed on the refractory. The origin of these species forming this vitreous phase is believed to be the refractory. Alumina graphite refractories contain secondary phases and impurities such as $\mathrm{SiO}_{2}, \mathrm{Na}_{2} \mathrm{O}, \mathrm{K}_{2} \mathrm{O}$ which can be reduced by the refractory carbon at steel-making temperatures, and generate gaseous species by the following reactions:

$$
\begin{aligned}
\mathrm{SiO}_{2}(\mathrm{~s})+\mathrm{C}(\mathrm{s}) & \rightarrow \mathrm{SiO}(\mathrm{g})+\mathrm{CO}(\mathrm{g}) \\
\mathrm{Na}_{2} \mathrm{O}(\mathrm{s})+\mathrm{C}(\mathrm{s}) & \rightarrow 2 \mathrm{Na}(\mathrm{g})+\mathrm{CO}(\mathrm{g}) \\
\mathrm{K}_{2} \mathrm{O}(\mathrm{s})+\mathrm{C}(\mathrm{s}) & \rightarrow 2 \mathrm{~K}(\mathrm{~g})+\mathrm{CO}(\mathrm{g})
\end{aligned}
$$

With the flow of molten steel inside the nozzle, a negative pressure is present from the outside inward. This "vacuum" tends to drive these gases from the refractory to the molten metal. At the steel/refractory interface, the partial oxygen pressure is in the order of $10^{-13}$ at. This oxygen potential is enough to re-oxidize and condense the gaseous species into a low melting point phase. This phase, at the operating temperature, dissolves either refractory or steel alumina to form a very viscous liquid that may constitute a sort of glue, whose composition is close to that of albite $\left(\mathrm{Na}_{2} \mathrm{O}-\mathrm{Al}_{2} \mathrm{O}_{3}-6 \mathrm{SiO}_{2}\right)$ :

$$
\begin{aligned}
2 \mathrm{Na}(\mathrm{g})+ & 6 \mathrm{SiO}(\mathrm{g})+\mathrm{Al}_{2} \mathrm{O}_{3} \text { (refractory) }+7 \underline{\mathrm{O}} \\
\rightarrow & \mathrm{Na}_{2} \mathrm{O}-\mathrm{Al}_{2} \mathrm{O}_{3}-6 \mathrm{SiO}_{2} \\
2 \mathrm{Na}(\mathrm{g})+ & 6 \mathrm{SiO}(\mathrm{g})+2 \underline{\mathrm{Al}}+10 \underline{\mathrm{O}} \\
\rightarrow & \mathrm{Na}_{2} \mathrm{O}-\mathrm{Al}_{2} \mathrm{O}_{3}-6 \mathrm{SiO}_{2}
\end{aligned}
$$

Here again, it is the carbon in the refractory which initiates the gas transfer of refractory sub-oxides, leading to the build-up on the nozzle wall. On the other hand, the magnitude of this mechanism's contribution to alumina build-up is unclear.

\subsubsection{Alumina formation through oxidation of the aluminium by carbon monoxide}

The predominant amount of alumina deposit occurs outside the thin layers described above. Its thickness tends to vary from a few millimetres to a few centimetres, and it is physically an heterogeneous composite of alumina and metallic nodules at room temperature. The particles of alumina take on a plate-like shape and their size does not exceed $20 \mu \mathrm{m}$ (Fig. 16). The source of this deposition is suggested to be oxidation of aluminium in the steel by oxygen due to the refractory (i.e. air permeation, redox equilibrium,...).

The sequence of relationships is thus:

$$
\begin{aligned}
\mathrm{CO}_{\text {(refractory) }} \rightarrow \mathrm{C}+\mathrm{O} & \\
\downarrow & \\
2 \mathrm{Al}+3 \mathrm{O} & \rightarrow \mathrm{Al}_{2} \mathrm{O}_{3}
\end{aligned}
$$

According to this reaction, if the refractory imposes a partial pressure of $\mathrm{CO}\left(P_{\mathrm{CO}}\right)$ greater than the one already in equilibrium 


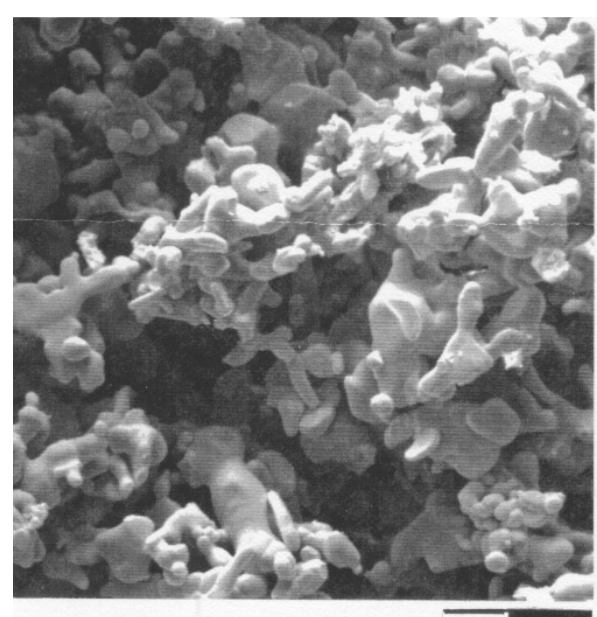

$\mathrm{x} 1000$

(a)

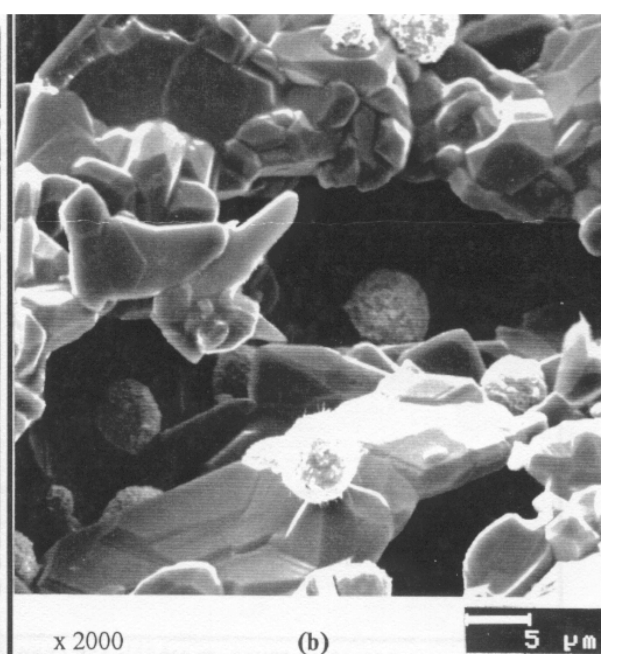

Fig. 16. Scanning electron microscopy microstructure of a alumina deposit in a submerged nozzle [20].

in the steel, then the reaction will proceed to the right and alumina will precipitate. The carbon content of the steel grade plays an important role in the decomposition of the refractory $\mathrm{CO}(\mathrm{g})$ and thus the formation of alumina. It is well known that alumina build-up occurs predominantly with low-carbon steel grades. This is because the $\mathrm{CO}(\mathrm{g})$ has an opportunity to be dissolved into the steel, providing oxygen to the aluminium. Also illustrated by this reaction is the increase in the carbon content in the steel C, resulting in the localized increased activity of aluminium, further driving this reaction to the right. Once again, it is the carbon in the refractory which triggers the formation of alumina.

It becomes clear that the carbon in the refractory may be responsible for the deposition of alumina at the interface between the steel and the refractory. The carbon acts:

- to increase the aluminium activity;

- as a redox agent that carries the oxygen from the refractory to the steel and in all cases it leads to the precipitation of alumina causing build-up. Under these conditions, removal of the carbon from the refractory should eliminate some of these alumina deposition mechanisms.

The clogging mechanism involves the following consequences:

- clogging takes place by in situ nucleation of alumina from the oxidation of alu- minium dissolved in the steel at the interface between the steel and the alumina graphite refractory. As a result, even if the steel is perfectly clean, clogging will still occur, suggesting that steel born inclusions are not the primary source of blockage;

- the alumina build up is caused by the gaseous transfer through the refractory sidewall. The permeability of the refractory and the air tightness of the assembly therefore play an essential part;

- the clogging phenomenon will be greater if the content of impurities and secondary phases (silica, alkalis) in the raw material from the refractory is higher. Improvements can be sought by using highly pure $\mathrm{A1}_{2} \mathrm{O}_{3}-\mathrm{C}$ mixtures, with as little silica and alkaline impurities as possible;

- carbon from the refractory is an increasing factor for the clogging mechanism. This questions the current use of carbon refractories in continuous casting and justifies a change to carbon-free refractory with little permeability and as inert as possible for the steel.

\subsubsection{Carbon-free refractories $[21,22]$}

The absence of refractory carbon during steel casting would be beneficial to prevent alumina build-up. Several approaches have 
been made to produce such materials. The properties of such refractories were targeted as follows:

- not permeable to gaseous exchange;

- chemically inert with steel;

- thermal shock resistant;

- mechanically resistant to steel flow.

Among the countermeasures, carbon-free inside liner nozzles and annular step nozzles have been developed with different technologies by suppliers and come to be widely used by many customers. The carbon-free materials do not supply $\mathrm{SiO}(\mathrm{g})$ and $\mathrm{CO}(\mathrm{g})$ which react with any dissolved $\mathrm{Al}$ in the molten steel to form network alumina. In addition, their stable surface condition due to the lack of decarburized refractory carbon is advantageous in retaining surface flatness and wettability.

\subsection{Tundish lining $[23,24]$}

The tundish refractory is usually made of magnesia and forsterite $\left(2 \mathrm{MgO}-\mathrm{SiO}_{2}\right)$ raw materials. Its lining thus may easily react with it, if the conditions, especially composition, allow it. This reaction will be made easier by the great porosity, thus the active surface, of the lining. These reactions can be positive (purifying role) or negative (polluting role): as a source of oxygen and silicon.

Due to the high potential of some oxides in the tundish lining, especially the silica and the iron oxides, reduction according to the following reactions are possible with oxygen pick up by the steel.

$$
\begin{aligned}
3\left(\mathrm{SiO}_{2}\right)_{\text {refract. }}+ & 4[\mathrm{Al}]_{\text {steel }} \rightarrow 3[\mathrm{Si}]_{\text {steel }} \\
& +2\left(\mathrm{Al}_{2} \mathrm{O}_{3}\right)_{\text {inclusion }} \\
3(\mathrm{FeO})_{\text {refract. }}+ & 2[\mathrm{Al}]_{\text {steel }} \rightarrow 3[\mathrm{Fe}]_{\text {steel }} \\
+ & \left(\mathrm{Al}_{2} \mathrm{O}_{3}\right)_{\text {inclusion }}
\end{aligned}
$$

Laboratory tests [25-27], had shown a relationship between the $\mathrm{FeO}$ content of the tundish refractory and the oxygen pick up by steel (see Fig. 17).

Plant trials as well as the laboratory experiments [23] demonstrate also a chemical transformation of the forsterite into the

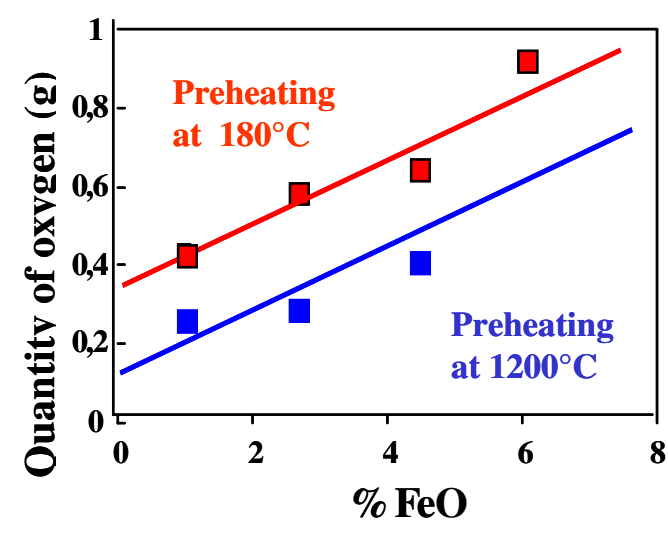

Fig. 17. Relationship between oxygen (caught by aluminium) and the $\mathrm{FeO}$ content of the tundish refractory (laboratory trials) [25, 27].

$\mathrm{MgO}-\mathrm{Al}_{2} \mathrm{O}_{3}$ spinel according the reaction:

$$
\begin{aligned}
& 3\left(2 \mathrm{MgO}-\mathrm{SiO}_{2}\right)_{\text {refract. }}+4[\mathrm{Al}]_{\text {steel }} \\
& \rightarrow 2\left(\mathrm{MgO}-\mathrm{Al}_{2} \mathrm{O}_{3}\right)_{\text {refract. }}+4(\mathrm{MgO})_{\text {refract. }} \\
& +3[\mathrm{Si}]_{\text {steel }}
\end{aligned}
$$

At the interface steel/refractory lining, a layer composed of $\mathrm{MgO}-\mathrm{Al}_{2} \mathrm{O}_{3}$ spinel is observed (Fig. 18). No oxides are formed in the steel or migrate to the steel due to this mineralogical transformation, which has no influence on steel cleanliness. Only a change of density of the lining resulting from the spinel formation could be observed. Spalling due to the different properties between the spinel layer and the $\mathrm{MgO}$-forsterite refractory lining can lead to $\mathrm{MgO}-\mathrm{Al}_{2} \mathrm{O}_{3}$ inclusions in the steel.

Potential hydrogen sources are also present in the tundish during casting. Substantial diffusion of water occurs when basic refractory tundish spray linings are used. Complete expulsion of the moisture cannot always be guaranteed even when the tundish is well pre-heated.

Figure 19 shows the evolution of the hydrogen content in steel during a sequence of three ladles. The initial hydrogen contents were $1.5 \mathrm{ppm}$. The hydrogen contents measured in the tundish using Heraeus ElectroNite technique, indicates hydrogen pick up during casting, particularly in the first heat of the sequence. In this context, to limit hydrogen pick up in the steel, it is important to improve the refractory composition and the preheating procedures of the tundish. 


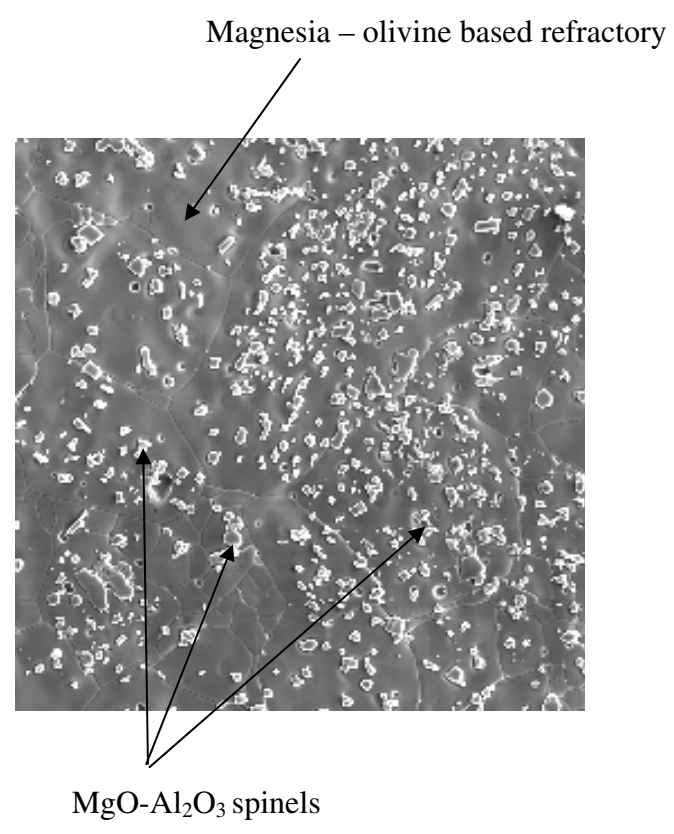

Fig. 18. Observation of spinel crystals at the steel/tundish lining-laboratory trials (SEM micrograph).

\subsection{Protection between ladle and tundish}

\subsubsection{The ladle shroud [28]}

Most of the time, this ladle shroud is made of alumina-graphite. The same reactions as in the submerged nozzle can take place. However, a few specificities may be noted:

- it is often reused;

- it is connected by a collecting nozzle to the ladle closing system using a high speed connection system. Consequently, manipulations can lead to a deterioration of its outside enamel and can increase its permeability. The connection is not always perfect and deteriorates during successive uses, favouring air intake. Consequences will be accelerated wear in the materials and re-oxidation of the metal, and thus its pollution.

\subsubsection{Sliding gate system [29]}

The sliding gate system for steel ladles consists of a mechanical assembly containing the refractory plates. Plates are different shapes: rectangular or circular.
The basic function of the sliding gate system is the control of metal flow-rate during teeming. This requires:

- reliable and robust mechanics;

- operating regularity;

- easy dismounting;

- easy replacement of worn parts;

- fast, easy upkeep.

The systems were then basically defined by mechanical engineers.

The second function is ensuring quality of the metal.

The plates of the sliding gate system are subjected to severe thermo-mechanical stresses which systematically lead to the cracking of the refractory in service. Such cracks are the cause of air leakage through the plates with adverse effects on the cleanliness of the steel and the wear of the refractory by corrosion.

Taking into consideration the complexity of thermo-mechanical conditions inside slide gate systems, especially inside refractory parts, is difficult and evolutions are slow. Today the design of most of the existing slide gates only takes little or no account of steel quality exigency, even if improvements have been made, generally based on certain empiricism. Radial and lengthways cracks, due to a concentration of stresses near the hole and a non-symmetry of the design affect the behaviour of plates (Fig. 20a). In consequence, relatively badly controlled plates wear is encountered due to variable air intake and an acceleration of wear between first and last heat because of the deterioration of refractory permeability. This deterioration has repercussions on metal cleanliness (oxygen pick up, inclusions).

In an optimised slide gate design (Fig. 20b), it would be better to take into account the thermo- mechanical stresses, to which the parts will be subjected, to define the refractory plates, their frame and their geometry in order to reduce and even suppress their in-operation cracking which may lead to re-oxidation of the metal by air intake.

\section{Conclusion}

The secondary steel making and casting is the key to the production of clean steels, with 


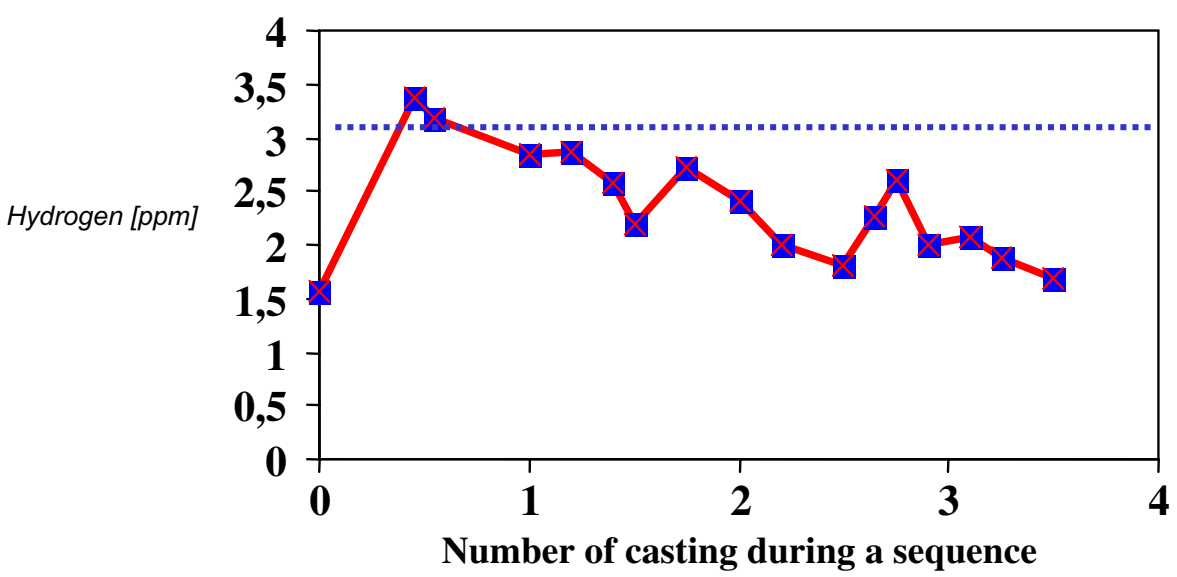

Fig. 19. Measurement of the hydrogen content in steel during a sequence of 3 ladles.

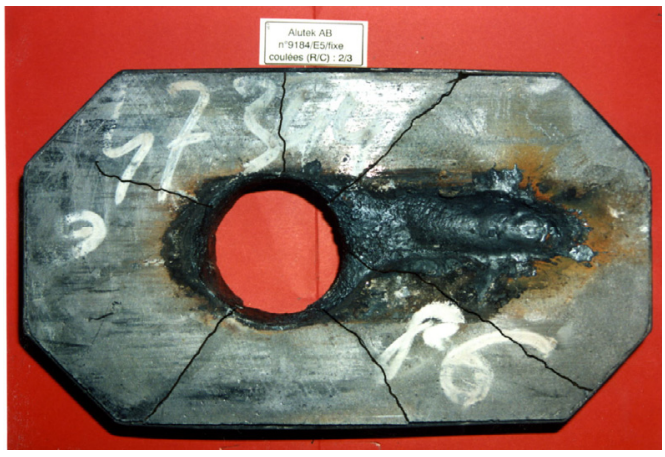

(a)

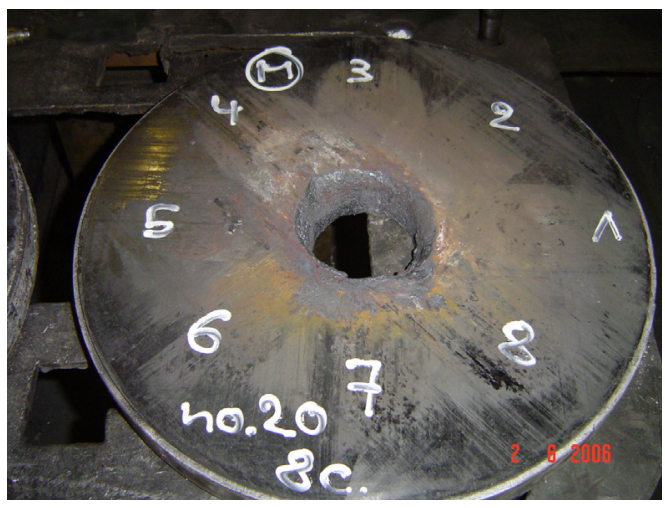

(b)

Fig. 20. Design of two plates of sliding gate system [29]. (a) Cracks in a slide gate $\rightarrow$ air leakage. (b) Optimised design $\rightarrow$ no.

a low content of residuals $\mathrm{P}, \mathrm{C}, \mathrm{O}, \mathrm{S}, \ldots$ and a low frequency of inclusions.

In this context, refractory products are not only strategic for the production of steel, but they also have a direct influence on the quality of elaborate grades. The future evo- lutions of the refractory products, in this field, will depend on such considerations. A good knowledge of the metal-slag-refractory product reactions is, consequently, necessary in order to better control steel making. Among all the points raised, we could mention all the developments that will limit the contribution of refractory products to clogging and carbon pick up, in conjunction with efforts of the metallurgists to produce clean steels.

\section{References}

[1] A.W. Cramb, Scand. J. Metall. 26 (1997) 2-7

[2] Ph. Blumenfeld, M. Puillet, J. de Lorgeril, D. Verrelle, Effect of service conditions on wear mechanisms of steel ladle refractories, in Proceedings of UNITECR '97, New Orleans, USA, 1997, pp. 13-219

[3] J. Poirier, M.L. Bouchetou, Corrosion of refractories, measurements and thermodynamic modeling, 10th International Conference of European Ceramic Society, Berlin, Germany, 2007, pp. 7- 21

[4] E. Blond, N. Schmitt, F. Hild, P. Blumenfeld, J. Poirier, J. Am. Ceram. Soc. 90 (2007) 154-162

[5] S. Zhang, W.E. Lee, Int. Mater. Rev. 45 (2000) 41-58

[6] P. Blumenfeld, Réfractaires et qualité metal, CESSID, 22 au 24 sept, 1998

[7] F. Qafssaoui, J. Poirier, JP. Ildefonse, P. Hubert, Refractories 1 (2005) 2-8

[8] D. Brachet, F. Masse, J. Poirier, G. Provost, J. Canada. Ceram. Soc. 58 (1989) 61-66

[9] K. Tsubota, I. Fukumoto, in Proceedings of the 6th International Iron and Steel Congress, Nagoya, Japan, 1990, Vol. 3, p. 637 
[10] C.W. Bale, P. Chartrand, S.A. Degterov, G. Eriksson, K. Hack, R. Ben Mahfoud, J. Melançon, A.D. Pelton, S. Petersen, Calphad 26 (2002) 189-228

[11] P. Riboud, R. Vasse, Revue de Métallurgie 82 (1985) 801-810

[12] G. Provost, Revue de métallurgie 2 (1987) 109122

[13] B. Bergmann, H. Wagner, N. Bannenberg, Revue de Métallurgie 4 (1989) 312-316

[14] F. Faries, P. Gibbins, C. Graham, Ironmak. Steelmak. 13 (1986) 26-31

[15] Slag Atlas, 2nd edition, edited by VDEh, Verlag Stahleisen $\mathrm{GmbH}, 1995$

[16] B. Breyny, Reactivity of periclase with carbon in magnesia graphite refractories, in Proceedings of UNITECR'89, Anaheim, USA, 1989, pp. 369-395

[17] H. Soulard, J. Lehmann, M. Boher, M.C. Kaerle, C. Gatellier, Interaction mechanisms between $\mathrm{MgO}-\mathrm{C}$ and Al-killed steels, in Proceedings of UNITECR '99, Berlin, Allemagne, 1999, pp. 301-303

[18] J. Poirier, M.L. Bouchetou, F. Qafssaoui, JP. Ildefonse, J. Eur. Ceram. Soc. 28 (2008) 15571568

[19] M.A. Guiban, J. Poirier, J. de Lorgeril, V. Guyot, C. Diot, E. Hanse, P. Dumas, Development of new continuous refractories to reduce alumina clogging, Mc Master Symposium, Toronto, Canada, 2-4 June, 1998

[20] J. Poirier, B. Thillou, Contribution of the refractory material of submerged nozzles to clogging, in Proceedings of the 37th International Colloquium on refractories, Aachen, Germany, 1994, pp. 114-118

[21] O. Fumihiko, Y. Noriaki, Y. Kazuhiro, T. Shigeaki, The evaluation of anti-clogging materials for submerged entry nozzles, in Proceedings of UNITECR'2005, Orlando, USA, 2005, pp. 776-780
[22] B. Prasad, J.K. Sabu, J.N. Tiwari, Design and development of anti-clogging nozzles for casting of aluminium killed steel, in Proceedings of the UNITECR'2007, Berlin, Germany, 2007, pp. 208-211

[23] H.A. Jungblut, T.G. Scherrmann, Investigations to minimize hydrogen pick-up during casting, 3rd European Conference on Continuous Casting, Madrid, 1988, pp. 707-714

[24] L. Dong-ha, L. Je-ha, C. Yong-Moon, U. Chang-Jung, Refinable lining material for clean steel in tundish, in Proceedins of the UNITECR'2007, Berlin, Germany, 2007, pp. 354-357

[25] J. Lehmann, M. Boher, H. Gaye, M.C. Kaerle, An experimental study of the interactions between liquid steel and a MgO-based tundish refractory, 2nd Inter. Symp. on advances in refractories for the metallurgy industry, Montréal, Québec, 1996, pp. 151-165

[26] M. Boher, J. Lehmann, C. Gatellier, M.C. Kaerle, Transfert de $\mathrm{Mg}$ des réfractaires de répartiteur vers un acier désoxydé SiMn, Les propriétés d'usage des réfractaires, Journées de rencontres industriesuniversités, Nancy, 1999

[27] J. Lehmann, M. Boher, M.C. Kaerle, CIM Bulletin 90 (1997) 69-74

[28] G. Provost, D. Gournay, J. de Lorgeril, F. Masse, La Revue de Métallurgie (1991) 55-63

[29] D. Verrelle, W. Rose, A. Gasser, J. Poirier, J. Bomboir, Improvement in linear ladle sliding gate system by rotation of the sliding plate at the ladle stand AISTech 2008, The Iron and Steel Technology Conference and Exposition, Pittsburgh, USA, 5-8 May, 2008 